\title{
Influence of Magnesium Sulfate on Self-Compacting Alum Sludge Concrete Incorporating with Pozzolanic Materials
}

\author{
Khalid M. Breesem ${ }^{1,2}$, Manal M. Abood ${ }^{1} \&$ Nurharniza Abdul Rahman ${ }^{3}$ \\ ${ }^{1}$ Faculty of Engineering and Technology Infrastructure, Infrastructure University Kuala Lumpur, Malaysia \\ ${ }^{2}$ Al-Furat Al-Awsat Technical University, Iraq \\ ${ }^{3}$ Inti International University, Malaysia \\ Correspondence: Manal M. Abood, Faculty of Engineering and Technology Infrastructure, Infrastructure \\ University Kuala Lumpur, (IUKL), Malaysia, 43000, Kuala Lumpur. E-mail: dr.manal@iukl.edu.my
}

Received: April 20, 2016

Accepted: May 5, 2016

Online Published: June 19, 2016

doi:10.5539/mas.v10n8p187

URL: http://dx.doi.org/10.5539/mas.v10n8p187

The research is financed by (Humid Tropic Centre Kuala Lumpur HTC KL under the grant number (98) dlm. PPS.HTC.21/4/5C).

\begin{abstract}
Self-compacting concrete (SCC) is a new revolution in concrete technology that made with no vibration equipment in placing and compaction. Totally, filling formwork and accomplishing full compacting under its own weight only, even when is attendance of crowded reinforcement. One of the issues that impact SCC durability is sulphate attack. The influence of magnesium sulfate attack was investigated for SCC having treated alum sludge (TAS) with ordinary Portland cement (OPC) at replacement ratios of 5\%, 10\%, 15\% and 20\% as well as, six SCC containing TAS, fly ash (FA), silica fume (SF) and natural zeolite (NZ) replaced cement by $15 \%$, $15 \%, 6 \%$ and $10 \%$, respectively. By visual inspection of all samples of SCC, there was no indication of deterioration on the surface of samples after 90 days and 180 days. In terms of compressive strength, there was developed with samples substituted OPC by $15 \%$ TAS compared with control SCC and the others SCC replacement levels. A similar conclusion was observed of the characteristics of SCC on weight compared with control SCC. Results proved that the SCC contain TAS have higher resistance against sulfate attack as well as the maximum value of mass loss and variation in weight are noted for the control SCC compared with SCC content TAS. Finally, in spite of the system of blended in SCC was investigated in several studies and so far, more investigations are required to fully explore its behavior, especially with new materials which is alum sludge that refer to the pioneering aspect of the present.
\end{abstract}

Keywords: sulfate attack, treated alum sludge, self-compacting concrete, cement replacement

\section{Introduction}

The Sulfate in solid form condition does not attack the concrete, but in solution form, sulfates react with the cement paste compounds leading to increase in size and then the deterioration of concrete. Due to (Neville, 2005) the effect of sulfate depends on the intensity of the interaction. The source of ions in solution is provided from the soil, ground water and some cases from seawater which is considered as an external influence and as one of the main problems affecting concrete durability, whereas, internal resource for sulfate ions come from the materials that used for making concrete such as sand and water as main resource and little quantities from gravel. The mechanism of this interaction is leach $\mathrm{Ca}^{+}$ion from the concrete matrix and replace by $\mathrm{Mg}^{-}$or $\mathrm{Na}^{+}$ion, outcomes cause increase in volume of concrete leading to appear cracking. There are extremely soluble sulfate salts in the form of magnesium sulfate $\left(\mathrm{MgSO}_{4}\right),\left(\mathrm{Na}_{2} \mathrm{SO}_{4}\right)$ and potassium sulfate $\left(\mathrm{K}_{2} \mathrm{SO}_{4}\right)$. The damage of the concrete matrix can be investigated by immersing the samples in the solution of magnesium sulfate or sodium sulfate or in a solution of both and then drying them. Sequentially, wetting and drying concrete accelerate the damage because of the crystallization of the salts within the pores. The effect of salts can be calculated through, loss in compression strength and elasticity, expansion of concrete, loss of weight and can be estimated by visual inspection.

The incorporating pozzolanic materials with cement enhance the durability of SCC to resist sulfate attack. These 
enhancements have been studied by many researchers. (Hassan et al., 2013) investigated the impact of the magnesium sulfate attack on SCC having FA, RHA, and GGBS with cement replacement ratios of $15 \%, 10 \%$, and $5 \%$, respectively. Coarse aggregate content was fixed at $45 \%$ of the solid volume, whereas fine aggregate content was fixed at $55 \%$ of the mortar volume with water to powder ratio of 0.53 . The sulfate resistance of SCC contents 15FA, 10RHA, and 5GGBS showed excellent durability to sulfate attack. In another study (Al-Akhras, 2006) conducted study on effects of MK to resist the sulfate attack. They demonstrated that concrete with $15 \% \mathrm{MK}$ exhibited good improving resistance to sulfate attack. Also (Behfarnia \& Farshadfar, 2013) carried out a study to assess sulfate resistance of SCC mixtures with SF, MK and Z as partially replaced with cement. Their results revealed that $\mathrm{MK}$ and $\mathrm{Z}$ have better effect than control SCC on resistance to magnesium sulfate attack whereas, there was an inactive effect of SF to resist magnesium sulfate attack. The smallest expansion happened in zeolite SCC. While, based on their results of compressive strength, ideal replacement ratio of SF, MK and Z were $15 \%, 15 \%$ and $10 \%$ Z, respectively. According to (Sabet et al., 2013; Ramezanianpouret al., 2012; Ranjbar et al., 2013; Türkmen et al., 2010; Ramezanianpour et al., 2012) stated that the using of NZ led to enhancement the durability of mortar and concrete.

Alum sludge (AS) is a waste product in the producing of potable water, in which about 2 million tons of AS are generated every year. When this raw alum sludge is treated by a thermal process, it will have cementitious properties. Treated alum sludge (TAS) has cementitious properties which can be investigated according to (ASTM C618, 2010). (Goncalves et al., 2004) carried out a study on the utilization of the sludge after treated with temperatures of $105^{\circ} \mathrm{C}, 450^{\circ} \mathrm{C}, 700^{\circ} \mathrm{C}$ and $850^{\circ} \mathrm{C}$. They reported that $\mathrm{AS}$ can be used in cement mortar with temperature of higher than $105^{\circ} \mathrm{C}$ and for incorporation of sludge in mortars can only reach after at not less $450^{\circ} \mathrm{C}$ while (Tantawy, 2015) determined the calcination temperature of alum sludge at $800^{\circ} \mathrm{C}$ and stated that it is adequate to enhance its pozzolanic properties. Also investigations were conducted and reported on reusing of AS by other researchers (Alqam et al., 2011; Zamora et al., 2008; Owaid et al., 2014; Sales et al., 2011) (Mohammed et al., 2013) (Awab et al., 2012; Miroslav, 2008).

The purpose of this paper is to evaluate and obtain an index for SCC deterioration due to sulfate attack and to explore the influence of TAS on SCC against sulfate attack. Control mix using OPC and SCC containing TAS, SF, FA, and NZ was performed to produce high workability SCC by following (EFNARK, 2002).

\section{Materials}

To achieve high workability, SCC is designed with limits on the nominal maximum size of the aggregate, the amount of aggregate, aggregate grading, high fine to coarse aggregate ratio, a low water/powder ratio (W/P) and high-range water-reducing admixture(Murthy et al., 2012). The materials were used as follows:

\subsection{Ordinary Portland Cement (OPC)}

Type I was used in all SCC mixes is which conforms to ASTM C-150. Physical properties and chemical analysis tests are presented in table 1 and 2, respectively.

\subsection{Aggregate}

The maximum size of coarse aggregate was limited to $10 \mathrm{~mm}$ with 2.67 and 0.63 of specific gravity and absorption, respectively. Fine aggregate has specific gravity and absorption of 2.66 and 0.86 , respectively. The grading of coarse and fine aggregates is shown in figure 1.

\subsection{Alum Sludge (AS)}

Chemical analysis of raw alum sludge (RAS) and treated alum sludge (TAS) is presented in table 2. In this study, RAS was collected from drinking water treatment plants in Malaysia.

\subsection{Fly Ash (FA)}

The substitution of cement by FA in the manufacture of SCC was used as $15 \%$ substitution of cement which leads to an improvement in the strength of SCC.

\subsection{Silica Fume (SF)}

Results in table 1 and 2 appear a specific surface area of SF about of $2105 \mathrm{~m}^{2} / \mathrm{kg}$ with specific gravity of 2.24 .

2.6 Natural Zeolite (NZ)

Clinoptilolite zeolite used in this study was in powder form. NZ mixture was prepared by adding $10 \% \mathrm{NZ}$ replacement for OPC. Physical properties and chemical composition are presented in tables 1and 2, respectively.

2.7 Superplasticizer

High water reducing agent (HWRA) based on polycarboxylic ether was used which is known commercially as Glenium 51. The typical properties of Glenium 51 (according to the manufacturer editions) are shown in table 3 which is free from chlorides and complies with ASTM C494, types A and F. 
Table 1. Physical properties of OPC, TAS, FA, SF, and NZ

\begin{tabular}{l|llll}
\hline Materials & Specific gravity & Specific surface area $\mathrm{m}^{2} / \mathrm{kg}$ & Median particle size $\left(\mathrm{d}_{50}\right) \mu \mathrm{m}$ & Color \\
\hline OPC & 3.1 & 330 & 19.681 & Grey \\
RAS & 2.36 & 702 & 31.713 & Light brown \\
\hline TAS & 2.57 & 1100 & 11.775 & Light orange \\
FA & 2.31 & 396 & 7.34 & Whitish grey \\
\hline SF & 2.24 & 2105 & 7.8 & Light grey \\
NZ & 2.16 & 572 & 46.550 & White \\
\hline
\end{tabular}

Table 2. Main elements of OPC, TAS, SF, FA, and NZ determined by XRF

\begin{tabular}{|c|c|c|c|c|c|c|c|c|}
\hline Name of compound & \multicolumn{2}{|c|}{ Chemical formula } & OPC & RAS & TAS & SF & FA & $\mathbf{N Z}$ \\
\hline Calcium oxide & \multicolumn{2}{|c|}{$\mathrm{CaO}$} & 65.12 & 0.17 & 0.22 & 0.91 & 4.85 & 1.05 \\
\hline Silicon dioxide & \multicolumn{2}{|l|}{$\mathrm{SiO}_{2}$} & 20.09 & 43.29 & 48.82 & 90.02 & 51.28 & 70.97 \\
\hline Aluminum trioxide & \multicolumn{2}{|l|}{$\mathrm{Al}_{2} \mathrm{O}_{3}$} & 5.60 & 32.19 & 39.42 & 0.32 & 24.37 & 9.10 \\
\hline Iron oxide & \multicolumn{2}{|l|}{$\mathrm{Fe}_{2} \mathrm{O}_{3}$} & 3.44 & 5.52 & 5.30 & 2.11 & 7.92 & 1.85 \\
\hline Magnesium oxide & \multicolumn{2}{|l|}{$\mathrm{MgO}$} & 1.53 & 0.33 & 0.44 & 2.45 & 2.05 & 0.87 \\
\hline Sulfur trioxide & \multicolumn{2}{|l|}{$\mathrm{SO}_{3}$} & 2.96 & 0.22 & 0.09 & 1.04 & 1.53 & 0.05 \\
\hline Potassium oxide & \multicolumn{2}{|l|}{$\mathrm{K}_{2} \mathrm{O}$} & 0.39 & 2.08 & 2.17 & 3.42 & 2.05 & 8.02 \\
\hline Sodium oxide & \multicolumn{2}{|l|}{$\mathrm{Na}_{2} \mathrm{O}$} & 0.09 & 0.13 & 0.08 & 0.08 & 0.56 & 4.08 \\
\hline \multicolumn{3}{|l|}{ Loss on ignition ( LOI) } & 2.05 & 12.3 & 2.55 & 0.73 & 0.44 & 8.07 \\
\hline \multicolumn{3}{|l|}{$\mathrm{SiO}_{2}+\mathrm{Al}_{2} \mathrm{O}_{3}+\mathrm{Fe}_{2} \mathrm{O}_{3}$} & - & 81.00 & 93.54 & 92.45 & 84.09 & 81.92 \\
\hline \multirow{2}{*}{\multicolumn{3}{|c|}{$\begin{array}{l}\text { Lime saturation factor } \\
\text { Main Compounds (Bog }\end{array}$}} & 1.00 & & & & & \\
\hline & & & y weigh & $\mathrm{fce}$ & & & & \\
\hline \multicolumn{9}{|c|}{ Tricalcium silicate $\left(\mathrm{C}_{3} \mathrm{~S}\right) \quad 60.86$} \\
\hline \multicolumn{2}{|l|}{ Dicalcium Silicate $\left(\mathrm{C}_{2} \mathrm{~S}\right)$} & 12.02 & & & & & & \\
\hline & 8.21 & & & & & & \\
\hline \multicolumn{2}{|c|}{$\begin{array}{l}\text { Tricalcium Aluminate }\left(\mathrm{C}_{3} \mathrm{~A}\right) \\
\text { Tetracalcium Aluminoferrite (C4AF) }\end{array}$} & 10.15 & & & & & & \\
\hline
\end{tabular}

Table 3. Typical Properties of Glenium 51

\begin{tabular}{lcclcc}
\hline Form & Colour & Relative density & $\mathrm{pH}$ & Transport & Labeling \\
\hline Viscous liquid & Light brown & $1.1 @ 20 \mathrm{C}^{\mathrm{o}}$ & 6.6 Not Classified as dangerous & Not hazard label required \\
\hline
\end{tabular}

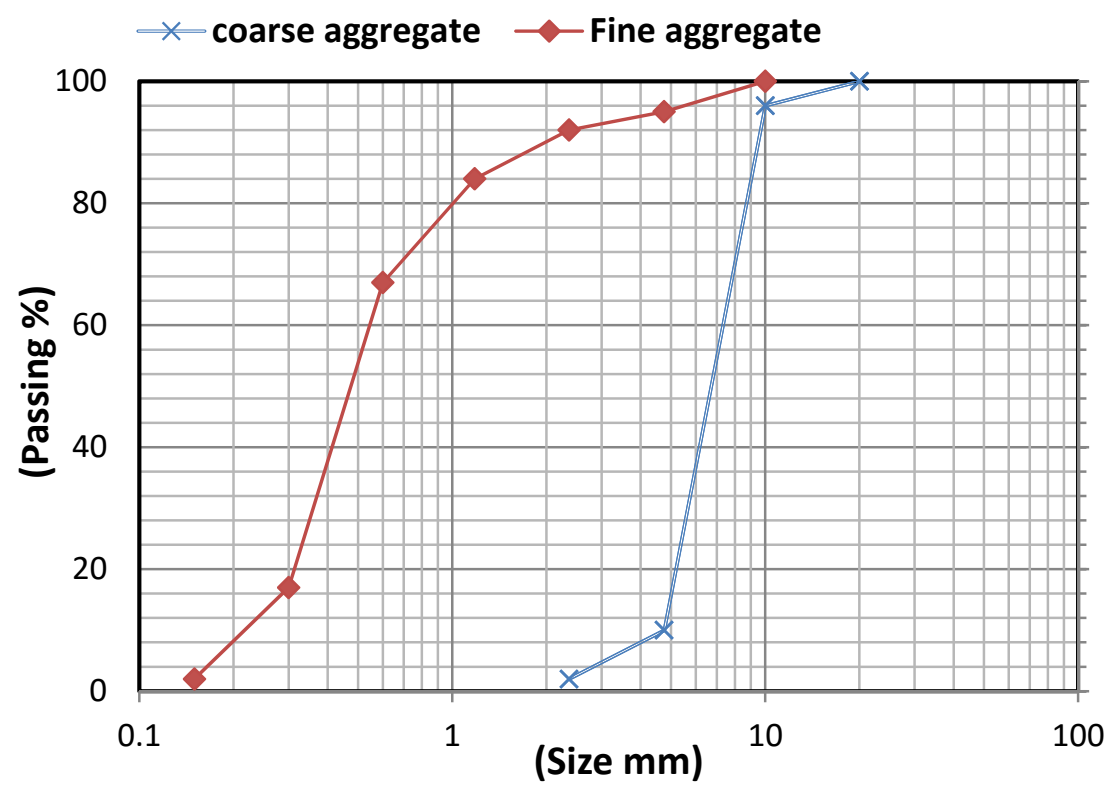

Figure 1. Grading distribution curves of coarse and fine aggregates 


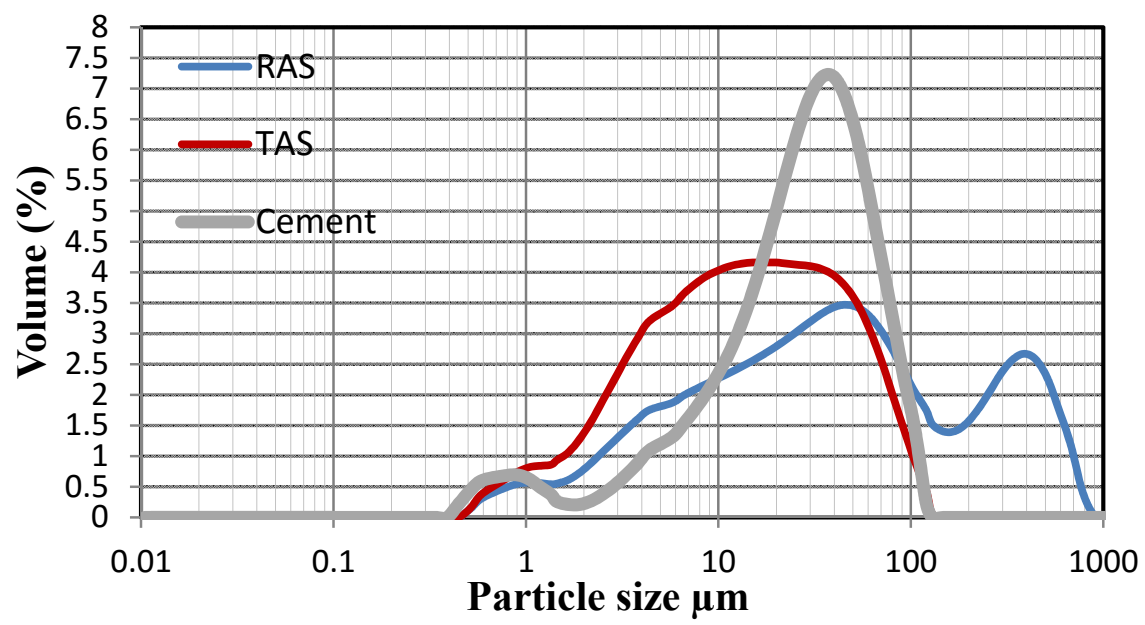

Figure 2. Particle Size Distribution curves of OPC, RAS, and TAS

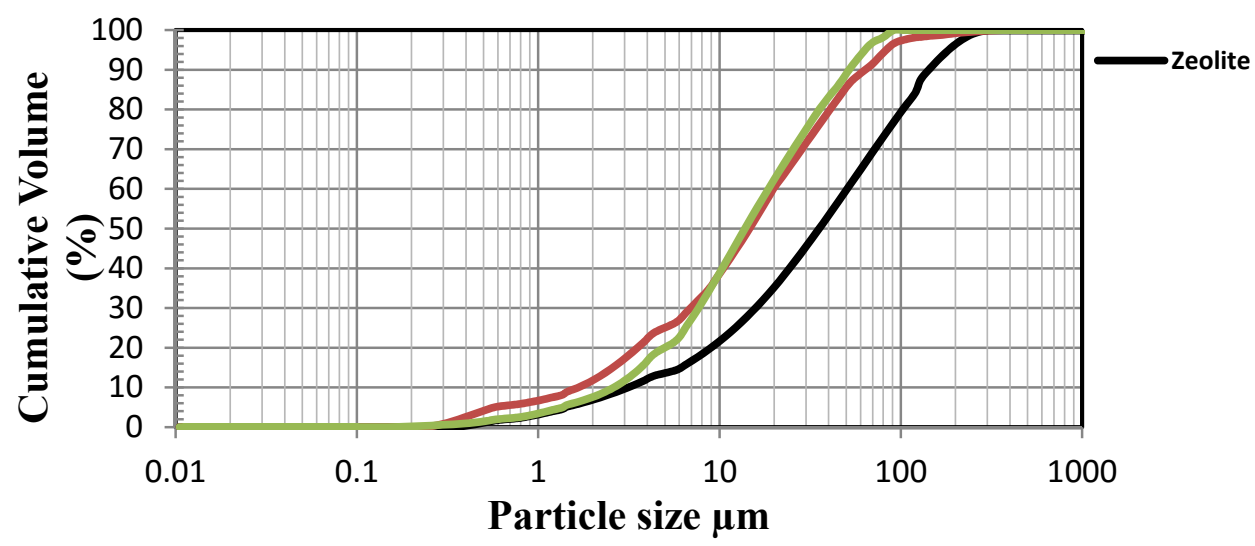

Figure 3. Cumulative grain size distributions curves of NZ, FA, and SF

\section{Experimental Procedure and Test Method}

\subsection{Mix Desidn}

(EFNARK, 2002) guide was followed to design SCC. This design must satisfy the criteria of filling ability, passability and segregation resistance, and then the proportions of materials are modified after obtaining a satisfactory SCC by evaluating fresh concrete tests. This mix design was achieved by following the steps of the first approach of EFNARK, these steps are:

Water/Powder ratio by volume of 0.80 to 1.10 . Typically water content does not exceed $200 \mathrm{liter} / \mathrm{m}^{3}$.

Total powder (cement + fillers) content ranges from 0.16 to 0.24 by volume of the mix $\left(400-600 \mathrm{~kg} / \mathrm{m}^{3}\right)$.

Coarse aggregate content normally 0.28 to 0.35 by volume of the mix.

The sand content balances the volume of the other constituents.

In this investigation, eleven mixtures were studied with a constant water cement ratio of (0.4). SCC without pozzolanic material (only OPC) namely SCCOPC100, four mixtures with TAS 5\%, 10\%, 15\%, and 20\% replacement of cement, and six SCC containing TAS, FA, SF and NZ replaced cement by $15 \%, 15 \%, 6 \%$ and $10 \%$, respectively were used. Table 4 shows mix proportion of SCC with different pozzolanic material levels. 
Table 4. Mix proportions of final SCC mixtures that were used to evaluate the attack by $\mathrm{MgSO}_{4}$

\begin{tabular}{lcccccccccc}
\hline \multirow{2}{*}{ Mix. ID } & $\begin{array}{c}\text { W/P } \\
\%\end{array}$ & $\begin{array}{c}\text { OPC } \\
\mathrm{kg}\end{array}$ & $\begin{array}{c}\text { TAS } \\
\mathrm{kg}\end{array}$ & $\begin{array}{c}\mathrm{FA} \\
\mathrm{kg}\end{array}$ & $\begin{array}{c}\mathrm{SF} \\
\mathrm{kg}\end{array}$ & $\begin{array}{c}\mathrm{NZ} \\
\mathrm{kg}\end{array}$ & $\begin{array}{c}\mathrm{S} \\
\mathrm{kg}\end{array}$ & $\begin{array}{c}\mathrm{G} \\
\mathrm{kg}\end{array}$ & $\begin{array}{c}\text { Water } \\
\mathrm{kg}\end{array}$ & $\begin{array}{c}\mathrm{S} . \mathrm{P} \\
\mathrm{Kg} / \mathrm{m}^{3}\end{array}$ \\
\hline SCCOPC100 & 0.4 & 500 & - & - & - & - & 894.6 & 745 & 200 & 4.5 \\
SCCOPC95TAS5 & 0.4 & 475 & 25 & - & - & - & 894.6 & 745 & 200 & 7.5 \\
SCCOPC90TAS10 & 0.4 & 450 & 50 & - & - & - & 894.6 & 745 & 200 & 8.25 \\
SCCOPC85TAS15 & 0.4 & 425 & 75 & - & - & - & 894.6 & 745 & 200 & 8.75 \\
SCCOPC80TAS20 & 0.4 & 400 & 100 & - & - & - & 894.6 & 745 & 200 & 11.5 \\
SCCOPC94SF6 & 0.4 & 470 & - & - & 30 & - & 894.6 & 745 & 200 & 6.63 \\
SCCOPC85FA15 & 0.4 & 425 & - & 75 & - & - & 894.6 & 745 & 200 & 3.9 \\
SCCOPC90NZ10 & 0.4 & 450 & - & - & - & 50 & 894.6 & 745 & 200 & 11 \\
SCCOPC79TAS15SF6 & 0.4 & 395 & 75 & - & 30 & - & 894.6 & 745 & 200 & 8.9 \\
SCCOPC70TAS15FA15 & 0.4 & 350 & 75 & 75 & - & - & 894.6 & 745 & 200 & 6.0 \\
SCCOPC75TAS15NZ10 & 0.4 & 375 & 75 & - & - & 50 & 894.6 & 745 & 200 & 9.5 \\
\hline
\end{tabular}

Note: W/P: water-powder ratio, S: sand, G: gravel, S.P: superplasticizer

\subsection{SCC Densities}

Densities of both SCC control and SCC with AS, FA, SF, and NZ were determined by weighing samples after 90 days immersed in $\mathrm{MgSO}_{4}$ solution and tap water. After calculating the volume of the mould which was $0.001 \mathrm{~m}^{3}$, the final densities were calculated by dividing the weight of each type of SCC mixture to the volume.

\subsection{Meganesium Attack}

For the proposed mixes, $100 \mathrm{~mm}$ cubes specimens were cast from each mixture. A magnesium sulfate as a fine white powder was dissolved in water to get $5 \%$ magnesium sulfate solution as well as tap water at $20{ }^{\circ} \mathrm{C}$ was prepared. According to (ASTM C1012, 2004),after 28 days of initial curing in water, the specimens were submerged in $\mathrm{MgSO}_{4}$ solution and tap water separately. Half of the specimens were placed in a solution of $\mathrm{MgSO}_{4}$ and the rest half in tap water. Through the period of curing, the concentration of the solution was checked every 120 days. There is an important to insure that be separate the specimens with space to guarantee a good exchange of the solution around the specimens until the test age. (ASTM C267, 2001) stated that can evaluate the deterioration of SCC specimens by visual inspection and by measuring the reduction in compressive strength using equation 1 below:

$$
\operatorname{CSR}(\%)=\operatorname{CSA}-\operatorname{CSM} / \operatorname{CSA} \times 100 \%
$$

Where CSR (\%) is the compressive strength reduction of specimens, CSA is the average compressive strength specimens under tap water (MPa), and CSA is the average compressive strength of specimens under submerging in $\mathrm{MgSO}_{4}$ solution (MPa) at the same age of curing. The test of compressive was conducted by taking out the specimens from tap water tank curing and $\mathrm{MgSO}_{4}$ solution and dried and thus tested at 90 and 180 days.

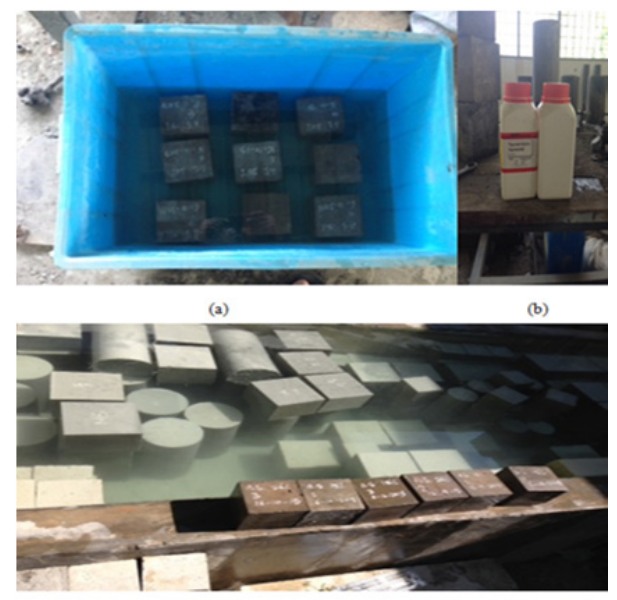

(c)

Figure 4. (a) SCC samples exposed to magnesium sulfate solution (b) $\mathrm{MgSO}_{4}$ cans(c) tap water tank 


\section{Results and Discuusion}

\subsection{Fresh Self-compacting Concrete}

Characteristics of SCC by flowability, passing ability, and segregation resistance were carried out and the results are shown in table 5. There was no bleeding or segregation of control SCC as well as SCC mixture containing TAS, FA, SF and NZ except the mixture SCCOPC80TAS20. To satisfy the criteria of filling ability, slump flow test which evaluates the horizontal free flow of SCC mixture without of obstructions was conducted while the tendency to segregation was evaluated by $T 50 \mathrm{~cm}$. Also the funnel test and funnel with refilling with concrete and left for 5 minutes to settle was conducted whereas the passing ability was determined by the L-box test. The estimation of the results was conducted according to (EFNARC, 2005). As shown to achieve that the using of superplasticizer at various amounts. On the other hand, the slump flow target was not achieved in mixture namely, SCCOPC80TAS20. It is clear that an increasing in replacement ratio required increasing in SP amounts. For example, mixture named SCCOPC100 was needed to $4.5 \mathrm{~kg} / \mathrm{m}^{3}$ from SP to achieve target flow slump while this not fulfill the minimum requirement SCCOPC80TAS20 in spite of used over dosage by $11.5 \mathrm{~kg} / \mathrm{m}^{3}$. (EFNARC, 2005) stated three flow classes, namely SF1, SF2, and SF3 which have slump flow (550 to 650) mm, (660to 750$) \mathrm{mm}$, and (760 to 850$) \mathrm{mm}$, respectively.

Table 5. Fresh SCC results

\begin{tabular}{llllll}
\hline Mix. ID & Slump flow $(\mathrm{mm})$ & $\mathrm{T}_{50}(\mathrm{sec})$ & $\mathrm{V}$-funnel & $\mathrm{TV}_{5 \min }(\mathrm{sec})$ & $\mathrm{L}-\mathrm{Box}(\%)$ \\
\hline SCCOPC100 & 843 & 3.84 & 6 & 6.76 & 0.82 \\
SCCOPC95TAS5 & 832 & 3.91 & 7.13 & 9.8 & 0.91 \\
SCCOPC90TAS10 & 781 & 4.00 & 7.32 & 10 & 0.90 \\
SCCOPC85TAS15 & 701 & 5.23 & 8.5 & 11.8 & 0.92 \\
SCCOPC80TAS20 & 547 & 7.84 & 16.15 & 21.78 & $0 . .61$ \\
SCCOPC94SF6 & 866 & 4.53 & 6 & 6.76 & 0.85 \\
SCCOPC85FA15 & 863 & 3.52 & 4.5 & 5.13 & 0.94 \\
SCCOPC90NZ10 & 653 & 4.68 & 6.83 & 9.11 & 0.84 \\
SCCOPC79TAS15SF6 & 870 & 2.7 & 8.2 & 9.6 & 0.91 \\
SCCOPC70TAS15FA15 & 795 & 4.3 & 11.5 & 13.8 & 0.86 \\
SCCOPC75TAS15NZ10 & 665 & 3.3 & 11.7 & 14.0 & 0.82 \\
\hline
\end{tabular}

\subsection{Rreduction in Compressive Strength Due to Sulfate Magnesium Attack}

The results in Figures 5, 6, 7, 8, and 9 demonstrated the reduction in compressive strength of both control SCC and SCC incorporates with alum sludge at various ratios compared to those cured in tap water at the same period. It is clear that the addition of TAS as pozzolanic material reduced the effect of $\mathrm{MgSO}_{4}$ after immersed in $\mathrm{MgSO}_{4}$ solution for all ages. The figures show the maximum strength submerged in $\mathrm{MgSO}_{4}$ solution compared to the control SCC strength was by SCC85AS15 as shown in figure 5 and 9 for 90 and 180 days, respectively. it is attributed that strength continues growing until a certain optimum value. In this case the optimum value of replacement cement by alum sludge was $20 \%$ and beyond that the results indicated for weakness in the matrix because of the reduction in strength hence, reduction in resistance to aggressive environment represented by $\mathrm{MgSO}_{4}$ solution. Replacement of cement by pozzolanic materials is considered one of the techniques that led to mitigate the sulfate attack because of the many benefits that acquired by this substitution. This substitution led to reduce amount of cement in paste and then less of $\mathrm{C} 3 \mathrm{~A}$.Furthermore, $\mathrm{Ca}(\mathrm{OH})_{2}$ is consumed by TAS due to pozzolanic reaction. As a result, it is improved packing with denser microstructure and less permeability (Chatterjee, 1982). 


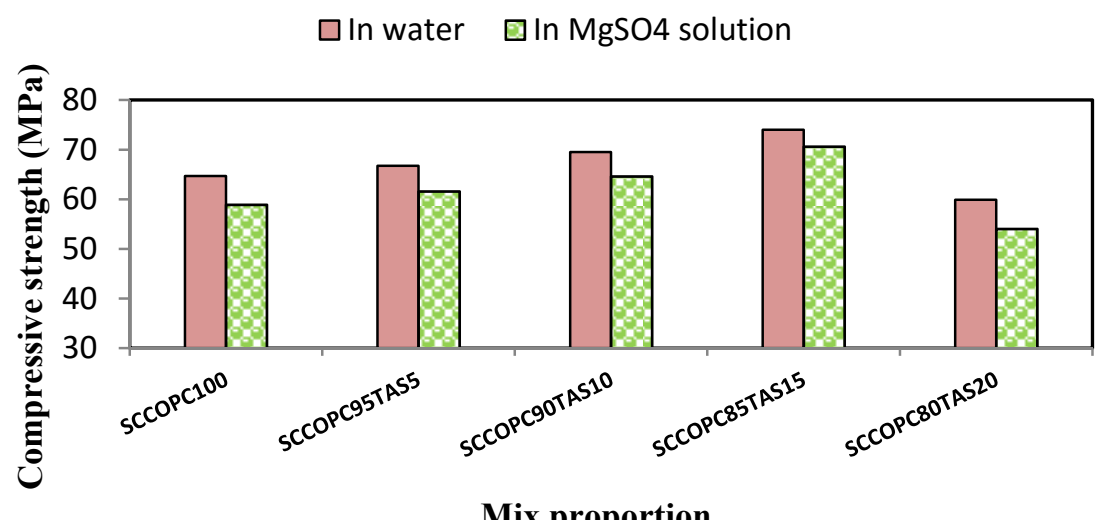

Figure 5. SCC Compressive strength of control and alum sludge SCC submerged in 5\% solution of $\mathrm{MgSO}_{4}$ after 90 days

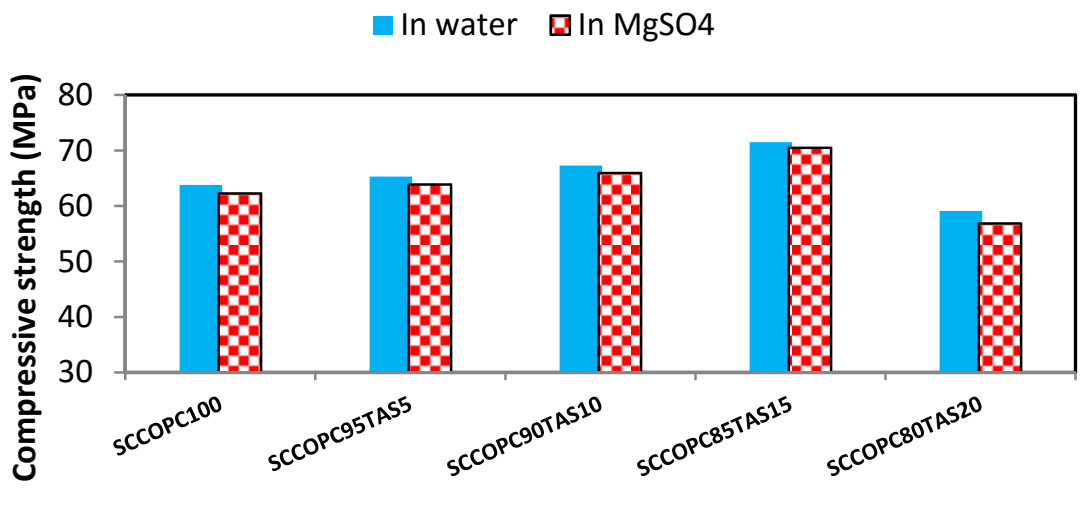

Mix proportion

Figure 6. SCC Compressive strength of control and alum sludge SCC submerged in 5\% solution of $\mathrm{MgSO}_{4}$ after 180 days

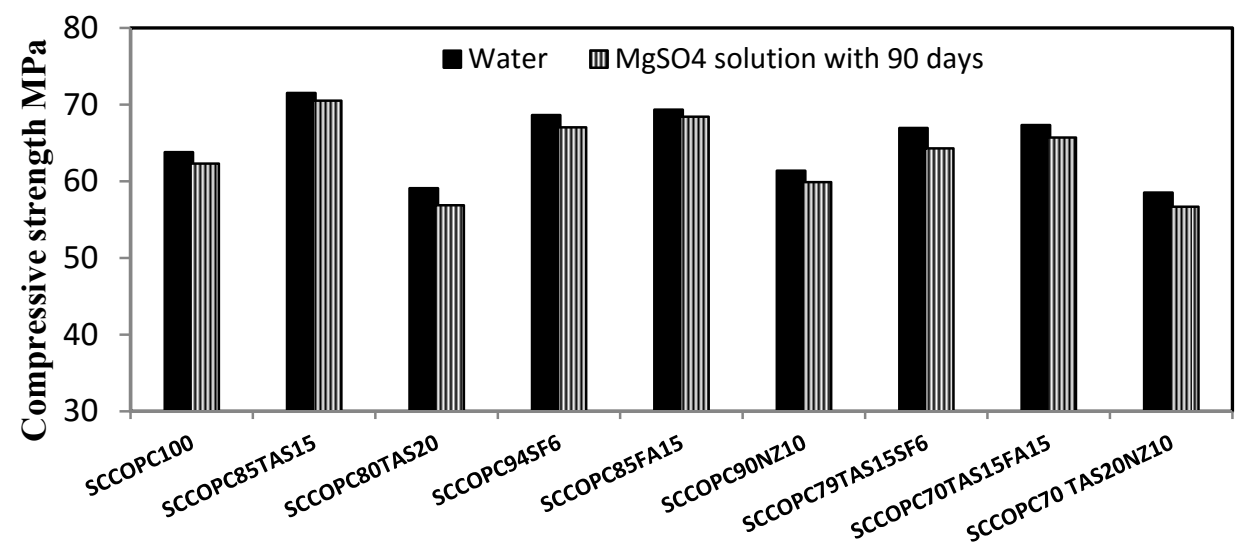

Mix symbol

Figure 7. SCC Compressive strength of control and SCC containing TAS, FA, SF and NZ submerged in 5\% solution of $\mathrm{MgSO}_{4}$ after 90 days 
Evaluation of compressive strength of SCC control and incorporates SCC with TAS, FA, SF and NZ samples exhibited that SCC mixtures incorporating, treated alum sludge, fly ash, silica fume and zeolite developed the maximum compressive strength, respectively, compared to control SCC at age of 90 days. According to the outcomes, the best binder of these pozzolanic materials, regarding to its durability of SCC to magnesium sulfate attack was TAS and then FA and NZ compared to the negative effect of silica fume. This action in samples having SF attributed to the formation of $(\mathrm{M}-\mathrm{S}-\mathrm{H})$ a non-adherent substance, in some cases with SCC which is similar to finding (Alexander et al., 2012) that stated when the attacking solution consists of magnesium sulfate $\left(\mathrm{MgSO}_{4}\right)$, all cement minerals are attacked, including C-S-H. In addition, $\mathrm{MgSO}_{4}$ directly attacks calcium silicate hydrate, transforming it into gypsum and weak magnesium silicate hydrate (M-S-H).

Generally, results showed that usage of pozzolanic material especially AS in SCC specimens exposed to $\mathrm{MgSO}_{4}$ attack reduced the compressive strength loss of specimens with different percentage of pozzolanic binders. Obtained results also revealed that was many benefits by using more than one material as a binder. It was a considerable effect of reduction attack on specimens immersed in magnesium sulfate solution.

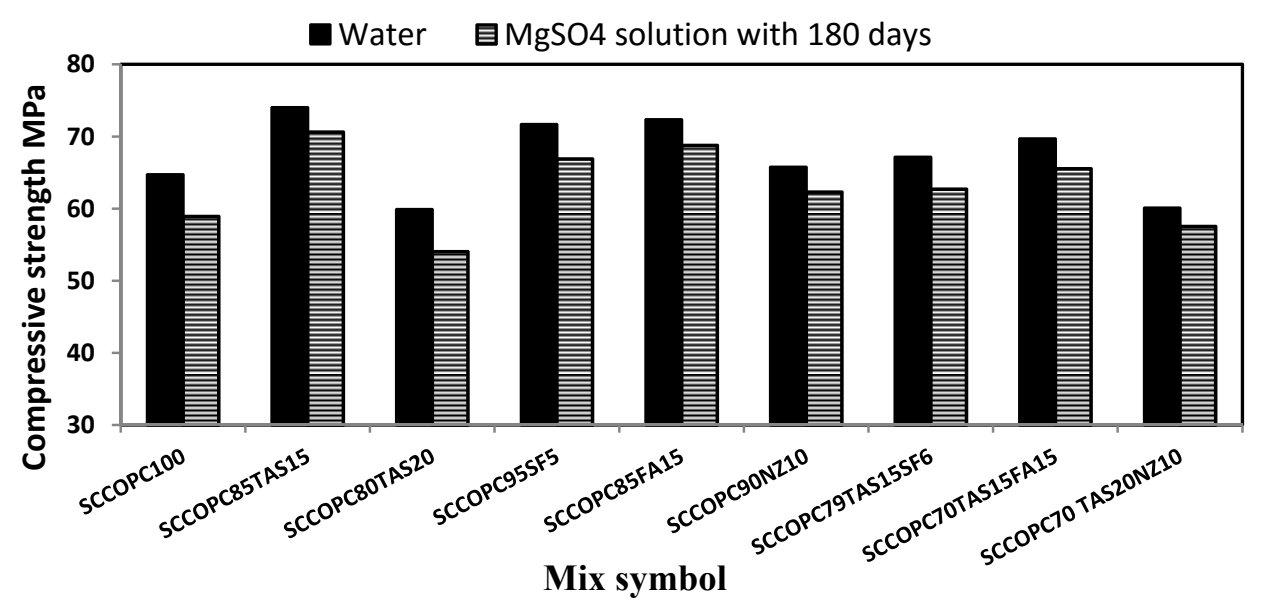

Figure 8. SCC Compressive strength of control and containing TAS, FA, SF and NZ submerged in 5\% solution of $\mathrm{MgSO}_{4}$ after 180 days

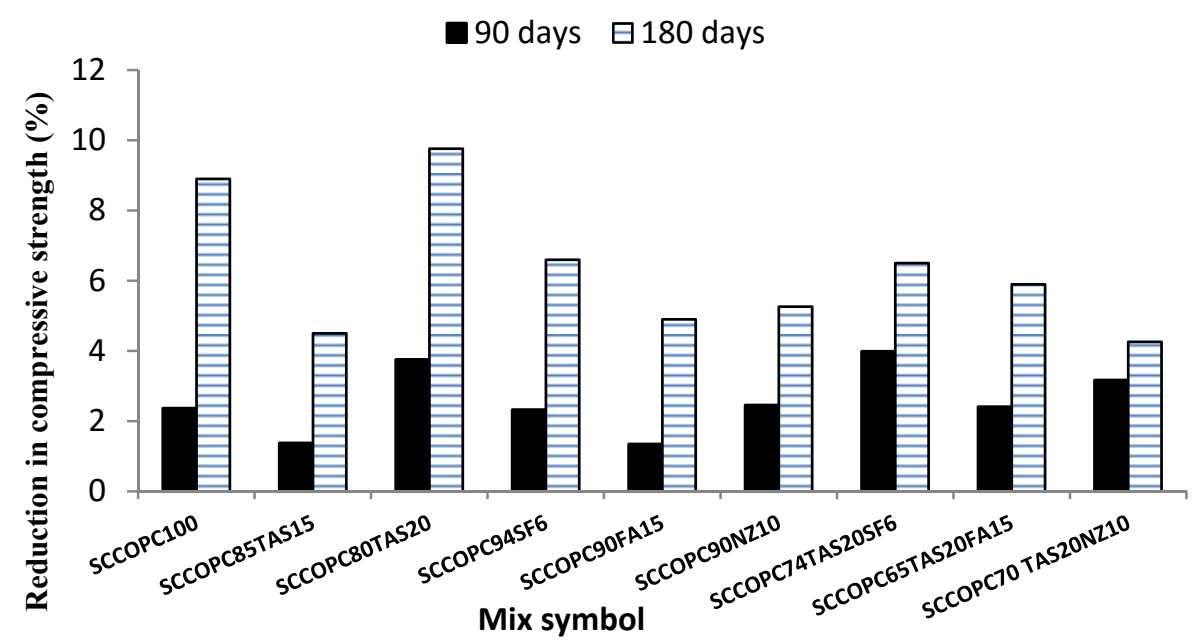

Figure 9. Reduction of SCC Compressive strength of control and containing TAS, FA, SF and NZ submerged in $5 \%$ solution of $\mathrm{MgSO}_{4}$ after 90 and 180 days 


\subsection{Deviation in Mass of SCC Samples Exposed to $\mathrm{MgSO}_{4}$ Solution}

Figure10 shows the loss in mass for SCC mixtures that stored in $\mathrm{MgSO}_{4}$ solution after 90 and 180 days compared to those masses in tap curing at the same age. It is clear from results that control mixture had the maximum value of mass while the mixture, namely SCCOPC85AS15 was less than the control mix and the FA, $\mathrm{NZ}$, and SF blended cement concrete gave in better resistance to sulfate attack; and again, the mass loss is considered as the best indicator for sulfate attack due to damage in the cohesiveness of the cement hydration products. The hydrated OPC reacts with magnesium sulfate and produce gypsum and $\mathrm{Mg}(\mathrm{OH})_{2}$, which cuases the damage of specimens of SCC as shown in equations 2 and 3.

$$
\begin{gathered}
\mathrm{MgSO}_{4}+2 \mathrm{Ca}(\mathrm{OH})_{2}+2 \mathrm{H}_{2} \mathrm{O} \rightarrow \mathrm{MgSO}_{4}+\mathrm{CaSO}_{4} \cdot 2 \mathrm{H}_{2} \mathrm{O}+\mathrm{Mg}(\mathrm{OH})_{2}+\mathrm{MgSO}_{4} \\
3 \mathrm{MgSO}_{4}+3 \mathrm{CaO} \cdot 2 \mathrm{SiO}_{2} \cdot 3 \mathrm{H}_{2} \mathrm{O}+8 \mathrm{H}_{2} \mathrm{O} \rightarrow 3\left(\mathrm{CaSO}_{4} \cdot 2 \mathrm{H}_{2} \mathrm{O}\right)+\mathrm{CaSO}_{4} \cdot 2 \mathrm{H}_{2} \mathrm{O}+3 \mathrm{Mg}(\mathrm{OH})_{2}+2 \mathrm{SiO}_{2} \cdot \mathrm{H}_{2} \mathrm{O}
\end{gathered}
$$

From the reaction above, the magnesium sulfate attack is more severe on SCC. (Polivka \& Brown, 1958) mentioned that from the results of loss in mass of concrete samples can estimate the grade of damage resulted from sulfate attack when compared those changes in length and strengths.

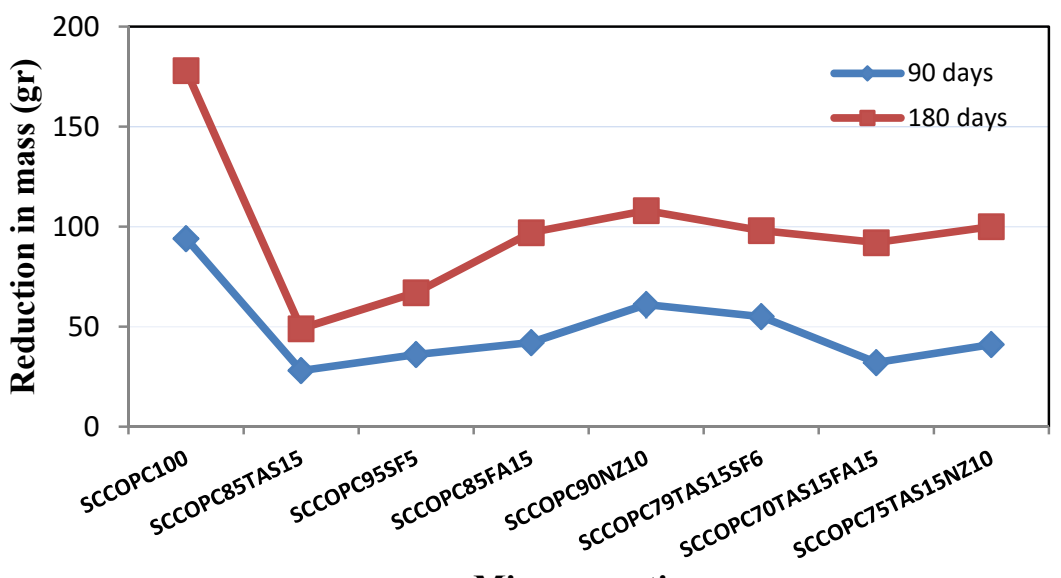

Mix proportion

Figure 10. Losses in mass between curing by tap water and stored in $\mathrm{MgSO}_{4}$ solution of SCC specimens after 90 and 180 days

\section{Conclusion}

The current study released following conclusions which can be drawn as follows:

- There was no bleeding or segregation of control SCC as well as SCC mixture containing TAS, FA, SF and NZ.

- The addition of TAS as pozzolanic material reduced the effect of $\mathrm{MgSO}_{4}$ after immersed in $\mathrm{MgSO}_{4}$ solution for all ages as well as the others pozzolanic materials.

- The best binder of these pozzolanic materials, regarding to its durability of SCC to magnesium sulfate attack was TAS and then FA and NZ compared to the negative effect of SF.

- It can be concluded that the loss in mass of samples stored in $\mathrm{MgSO}_{4}$ solution is the loss of $\mathrm{Ca}(\mathrm{OH})_{2}$ and other of cement products. So, to mitigate the attack by magnesium sulfate, the pozzolanic materials can be used as a substitution of cement which act as a consumer for $\mathrm{Ca}(\mathrm{OH})_{2}$ and as results lead to form stability for concrete matrix.

Generally, replaced cement by TAS, FA, NZ, and SF in SCC develops its resistance to sulfate attack. Pozzolanic materials with suitable fineness will improve its resistance due to the increasing pozzolanic activity. Furthermore; It is promising to make SCC in Malaysia by using alum sludge which is available as a by-product from drinking water treatment plants after treating it. It is remarkable that they must carefully choose to be successful a mix proportion in term of durability that will reach a good behavior with aggressive environment. 


\section{References}

Al-Akhras, N. M. (2006). Durability of metakaolin concrete to sulfate attack. Cement and Concrete Research, 36(9), 1727-1734. http://dx.doi.org/10.1016/j.cemconres.2006.03.026

Alexander, M., Bertron, A., \& Belie, N. D. (2012). Performance of Cement-based Materials in Aggressive Aqueous Environments (Vol. 10). http://dx.doi.org/10.1007/978-94-007-5413-3

Alqam, M., Jamrah, A., \& Daghlas, H. (2011). Utilization of Cement Incorporated with Water Treatment Sludge. Jordan Journal of Civil Engineering, 5(2), 268-277.

ASTM C1012. (2004). Standard Test Method for Length Change of Hydraulic-Cement Mortars Exposed to a Sulfate Solution. In Annual Book of ASTM Standards. West Conshohocken (PA).

ASTM C267. (2001). Standard Test Methods for Chemical Resistance of Mortars, Grouts, and Monolithic. In Annual Book of ASTM Standards.

ASTM C618. (2010). Standard Specification for Coal Fly Ash and Raw or Calcined Natural Pozzolan for Use a Mineral Admixture in Concrete. ASTM C 618,Annual Book of ASTM Standards (Vol. 04). http://dx.doi.org $/ 10.1520 / \mathrm{C} 0618$

Awab, H., Paramalinggam, P. T. T., Rahim, A., \& Yusoff, M. (2012). Characterization of Alum Sludge for Reuse and Disposal. Malaysian Journal of Fundamental \& Applied Sciences, 8(4), 209-213.

Behfarnia, K., \& Farshadfar, O. (2013). The effects of pozzolanic binders and polypropylene fibers on durability of SCC to magnesium sulfate attack. Construction and Building Materials, 38, 64-71. http://dx.doi.org /10.1016/j.conbuildmat.2012.08.035

Chatterjee, C. S. and M. K. (1982). Sulfate resistance of portland-pozzolanic cements in relation to strength. Cement and Concrete Research, 12, 726-734.

EFNARC. (2005). The European Guidelines for Self-Compacting Concrete; specification, production and use. http://www.efnarc.org/pdf/SCCGuidelinesMay2005.pdf

EFNARK. (2002). Specification and Guidelines for Self-Compacting Concrete. European Federation of Producers and Applicators of Specialist Products for Structures. http://dx.doi.org /0953973344

Goncalves, A., Esteves, A. M., \& Carvalho, M. (2004). Incorporation of sludges from a water treatment plant in cement mortars. In International RILEM Conference on the Use of Recycled Materials in Buildings and Structures. Barcelona, Spain.

Hassan, A., Mahmud, H. B., Jumaat, M. Z., Alsubari, B., \& Abdulla, A. (2013). Effect of Magnesium Sulphate on Self-Compacting Concrete Containing Supplementary Cementitious Materials. Advances in Materials Science and Engineering.

Miroslav, K. (2008). Opportunity for water treatment sludge re-use. GeoScience Engineering, LIV(1), 11-22.

Mohammed, H., Hamid, R., Rozaimah, S., Abdullah, S., Tan, N., \& Raihan, M. (2013). Physical and Mechanical Properties of High Performance Concrete with Alum Sludge as Partial Cement Replacement. Jurnal Teknologi, 2, 105-112.

Murthy, K. M., V, N. R. A., Reddy, R., Vijaya, I. V., \& Reddy, M. (2012). Mix Design Procedure for Self Compacting Concrete. IOSR Journal of Engineering (IOSRJEN), 2(9), 33-41.

Neville, A. M. (2005). Properties of concrete. 4th and final edition.

Owaid, H. M., Hamid, R., \& Taha, M. R. (2014). Influence of thermally activated alum sludge ash on the engineering properties of multiple-blended binders concretes. Construction and Building Materials, 61, 216-229. http://dx.doi.org /10.1016/j.conbuildmat.2014.03.014

Polivka, M., \& Brown, E. (1958). Influence of various factors on sulfate resistance of concretes containing pozzolan. Proceedings.

Ramezanianpour, A. A., Kazemian, A., Sarvari, M., \& Ahmadi, B. (2012, May). Use of Natural Zeolite to Produce Self-consolidating Concrete with Low Portland Cement Content and High Durability. Journal of Materials in Civil Engineering. http://dx.doi.org /10.1061/(ASCE)MT.1943-5533.0000621

Ramezanianpour, A. A., Kazemian, A., Sarvari, M., Ahmadi, B., \& Moghadam, M. A. (2012). Investigation of long term durability of natural incorporated Eco-SCC zeolite (pp. 17-19). In 10th International Congress on Advances in Civil Engineering. 
Ranjbar, M. M., Madandoust, R., Mousavi, S. Y., \& Yosefi, S. (2013). Effects of natural zeolite on the fresh and hardened properties of self-compacted concrete. Construction and Building Materials, 47, 806-813. http://dx.doi.org /10.1016/j.conbuildmat.2013.05.097

Sabet, F. A., Libre, N. A., \& Shekarchi, M. (2013, January). Mechanical and durability properties of self consolidating high performance concrete incorporating natural zeolite, silica fume and fly ash. Construction and Building Materials, 44, 175-184. http://dx.doi.org /10.1016/j.conbuildmat.2013.02.069

Sales, A., Souza, D. F. R., \& Almeida, F. D. C. R. (2011). Mechanical properties of concrete produced with a composite of water treatment sludge and sawdust. Construction and Building Materials, 25(6), 2793-2798. http://dx.doi.org /10.1016/j.conbuildmat.2010.12.057

Tantawy, M. A. (2015). Characterization and pozzolanic properties of calcined alum sludge. Materials Research Bulletin, 61, 415-421. http://dx.doi.org /10.1016/j.materresbull.2014.10.042

Türkmen, I., Öz, A., \& Aydin, A. C. (2010). Characteristics of workability, strength, and ultrasonic pulse velocity of SCC containing zeolite and slag. Scientific Research and Essays, 5(15), 2055-2064.

Zamora, R. M. R., Alfaro, O. C., Cabirol, N., Ayala, F. E., \& Moreno, A. D. (2008). Valorization of Drinking Water Treatment Sludges as Raw Materials to Produce Concrete and Mortar. American Journal of Environmental Sciences 4, 4(3), 223-228.

\section{Copyrights}

Copyright for this article is retained by the author(s), with first publication rights granted to the journal.

This is an open-access article distributed under the terms and conditions of the Creative Commons Attribution license (http://creativecommons.org/licenses/by/3.0/). 